Article

\title{
Protestant Political Theology and Pluralism: From a Politics of Refusal to Tending and Organizing for Common Goods
}

\author{
Emily Dumler-Winckler \\ Department of Theological Studies, Saint Louis University, St. Louis, MO 63103, USA; \\ emily.dumlerwinckler@slu.edu
}

Received: 28 June 2019; Accepted: 8 September 2019; Published: 10 September 2019

\begin{abstract}
Protestant perspectives on pluralism in political theology are predictably plural. While prevalent narratives of modern decline bemoan Protestant pluralism and its ostensive side-effects, others celebrate pluralism as a good in its own right. One aim of this essay is to display the diverse perspectives in Protestant political theology regarding political theology itself, pluralism, secularism, and democracy, while clarifying and refining these terms. I do so by considering each theme in turn. Finally, I consider the ways that religious dissenters of the 1790s defy prominent depictions of Protestantism, even as they exemplify the plurality at its core. The dissenters wed an ancient legacy of reflection on theological virtues such as charity to appeals for human and women's rights, and suggest that love of country, neighbor, alien and God is central to protestant political theology. Given the plurality inherent in Protestantism, Christianity, and modern democratic societies alike, we have good reasons, I argue, to turn from a politics of refusal to one of tending and organizing for goods shared in common.
\end{abstract}

Keywords: political theology; protestantism; pluralism; secularism; democracy; charity; love; justice; rights

To risk stating the obvious, Protestant perspectives about pluralism—religious, cultural, ethnic, and moral-are predictably plural. ${ }^{1}$ For those well-versed in the history of Protestantism, this comes as no surprise. The Protestant Reformation, a movement initially intended to reform ecclesial authority from within the Roman Catholic Church, resulted in the splintering of Protestant churches into a plurality of denominations and communities of faith. This plurality is no less conspicuous in protestant political theology. Here we find a range of views about pluralism and related concepts, such as: secularism, liberalism, democracy, tolerance, and the common good. Several recurrent and prevalent declension narratives about modernity, among modernity's religious despisers, bemoan the plurality of Protestantism and (with a combination of nostalgia or resentment) long for the institutional and moral unity of the medieval church. ${ }^{2}$ By these lights, the Protestant Reformation is the source of modern ills.

1 (Hovey and Phillips 2015, p. 46). Hak Joon Lee in the chapter on public theology names three types of pluralism-religious, cultural, and ethic. I am also interested here in moral and theological pluralism, as some of the central figures I engage are primarily concerned with these forms.

2 The epithet "modernity's religious despisers" or "modernity's despisers" used throughout are not antagonistic, but rather a play on Schleiermacher's "religion's cultured despisers." The declension narratives I have in mind include the following: (MacIntyre 2007; Harrison 2015; Milbank et al. 1998). These narratives share a family resemblance. MacIntyre tells a story of decline. Gregory, while less nostalgic, laments the loss of institutionalized Christendom in the medieval era. With regard to the virtues in modernity, as we will see, the plot lines are strikingly similar. Modernity has arrived and virtue has departed, or so the declensionist story goes. See also (Hauerwas 2015b; Lloyd 2012). All citations from Hauerwas in this essay, unless otherwise noted, come from this 2015 text. Hauerwas and Lloyd do not present narratives of modern decline. Nonetheless, like those above, their portrait of Protestantism is more uniform than the one I present here. Gregory suggests that the 
In short, they argue that Protestantism and its concomitant hyper-pluralism render common goods obsolete, modern virtue a contradiction. ${ }^{3}$ Some protestant theologians have adopted these narratives. They join modernity's despisers espousing what we might call a "politics of refusal." ${ }^{4}$ Downplaying the pluralism internal to Christianity, they lament the religious and moral pluralism of modern societies. One aim of this essay is to display some of the diverse perspectives within Protestant political theology regarding political theology itself, pluralism, secularism, and democracy, pace those who elide the plurality internal to Christianity and specifically Protestantism. ${ }^{5}$ Another aim is to respond to those who lament Protestant plurality and pluralism broadly by featuring Protestant political theologians who provide a politics of tending and organizing for the sake of shared good as a hopeful alternative to a politics of refusal. ${ }^{6}$ Pluralism - protestant, religious, cultural, ethnic, and ethical-they suggest, is simply a feature of our common life. Yet, this pluralism does not render common goods or modern virtues obsolete.

In the end, we will see that those who affirm the existence of shared goods, and who advocate tending and organizing for them, have historical precedent in eighteenth-century Protestant dissenters. Moreover, the dissenters of the 1790s in Britain defy the depictions of Protestantism, hyper-pluralism, virtues, and rights among modernity's despisers, at the precise historical moment, the incantatory date of 1789, that the latter use to mark the modern. According to Brad Gregory's narrative: 1. the Reformation replaced the ethics of virtue, which gave cohesion to the notion of the common good, with an ethics of rights, and 2. what he calls "hyperpluralism" has made it nearly impossible to adjudicate competing claims about goods, let alone common goods. Far from the kingdom of God, the Reformation ushered in "the kingdom of whatever" (112). Rather than eclipsing rights with virtues, however, the dissenters wed appeals for human and specifically women's rights to virtues such as charity, justice, and candor. Indeed, they suggest that both rights and virtues are among the goods political communities share in common. Their advocacy for religious toleration and freedom among other rights grew out of their experience of intra-protestant persecution. ${ }^{7}$ They suggest that protestant political theology is concerned not only or primarily with questions of sovereignty and statehood, but with civil rights, justice, and the love of country, neighbor, alien and God. Given the plurality inherent in Protestantism, Christianity, and democratic societies alike, we have good reasons to turn from a politics of refusal to one of tending and organizing for the sake of such provisional yet substantial goods shared in common.

Protestant Reformation unintentionally had the effect of secularizing society and that Protestant pluralism, secularism, relativism, liberalism, and democracy all come packaged together. Hauerwas, to his credit, notes that "Christians have not claimed that our vocabularies—and the plural is important-are finished" (158). Nonetheless, his conclusion that "the church does not have a politics, but rather the church is God's politics for the world" belies the plurality of ecclesial polities and their significance for the Protestants who spilled much blood and ink in their defense (see chapter 9 "How to (Not) be a Political Theologian" specifically 190). Finally, Lloyd raises important questions and points about race, colonialism, and political theology and yet paints Protestantism and "Protestant hegemony" with a broad brush that elides the plurality of protestant perspectives and commitments.

3 (Bowlin and Latham 2016).

4 (Farneth 2019). I borrow this basic distinction from Farneth, who draws a distinction between those who endorse a politics of refusal (from the likes of Giorgio Agamben and Slavo Zizek to adherents of Radical Orthodoxy, and the "zombie narratives," to borrow a phrase from Thomas Lewis, that have followed Alasdair MacIntyre's declension narrative) and those who advocate for a "politics of tending" (such a Sheldon Wolin who coined the term and James K. Smith whom Farneth commends for adopting this political mode) and I add a "politics of organizing" (such as those elaborated by Jeffrey Stout in Blessed are the Organized and Luke Brethertson in Resurrecting Democracy) for specific political ends and goods.

5 For the purposes of this essay, I consider the Protestant tradition as a broad tent that includes any Christian denominations or movements that began after the Reformation and do not belong to the Roman Catholic or Eastern Orthodox church. At the same time, I draw on the work of theologians who most explicitly identify themselves or their work as Protestant in some respect, which is a narrower range.

6 Again, the list would be expansive, were I to consider all the theologians and Christian ethicists who provide resources for a politics of tending or organizing. I limit myself here to Protestant theologians and ethicists who either explicitly identify their work with political theology and address questions about pluralism, secularism, and democracy (or reject the term while opting for a another, such as Hauerwas). But I also focus on those who have responded to modernity's despisers with a more affirming account of these features of modern life.

7 (Stevens 2018). 


\section{Political Theology}

In order to consider whether there is anything distinctively Protestant about Protestant political theologies of pluralism, it will help to ask a prior question. What is Protestant political theology? Indeed, how do Protestant's conceive of, identify with, or reject political theology? Here, as one might expect, we find considerable plurality. To begin to answer these questions it will help to consider the ways political theology is conventionally understood in a narrow sense as well as in a much broader sense.

In the narrower sense, political theology names a conversation or debate about the relation between theology and politics that emerged in the interwar period of the twentieth century in Germany, and came to include primarily Catholics, Jews, and Protestants. Carl Schmitt, the notorious German Catholic, jurist, and prominent member of the Nazi party, is perhaps the most influential catalyst for the academic discipline of political theology. His 1922 text Politishe Theologie, was a response to Mikhail Bakunin's 1871 text "The Political Theology of Mazzini and the International." Other prominent figures include the Catholic theologian Johannes Baptist Metz, Catholic historian Erik Peterson, Jewish philosophers Walter Benjamin and Ernst Bloch, and Protestant theologians such as Dorthee Sölle and Jurgen Moltmann. This German stream of thought was primarily interested in the ways that religious concepts such as sovereignty and natural and divine law were secularized in modern political discourse. $^{8}$

In the broadest sense, Protestants have understood political theology in two distinct but compatible ways. First, some Protestant political theologians, such as Vincent Lloyd and Ruben Rosario-Rodriguez, insist that plurality and diversity are crucial for political theology-a term they use to describe theological reflection on politics from any theological perspective (whether Abrahamic and other faith traditions) in any place and time. ${ }^{9}$ Second, other Protestant political theologians, such as Luke Bretherton, Sarah Coakley, and Mark L. Taylor for all their differences, signal the inherently political contexts and nature of all theological discourse and practices. ${ }^{10}$ In this sense, all theology is political theology because it arises in political contexts among political animals (human beings), adopts and adapts political terms, and is formed by and transforms polities. This is the case in the twenty-first century no less than the first.

Taylor and Elizabeth Schussler Fiorenza, among others, have shown how the earliest Christian communities appropriated the language of the Roman Empire for distinctively Christian and subversive ends. New Testament terms such as gospel (euangelion) and savior (soter), were used to proclaim the good news of Jesus Christ as savior, rather than the news of Roman military victories under the Emperor (soter), to announce the peace of Christ rather than the Pax Romana. The Apostle Paul posed a direct challenge to Roman imperial cults from Caesar Augustus onward by claiming Jesus as Lord (Kyrios) and Savior. So too, in both the Apostles' and the Nicene Creeds, Pontius Pilate is the only human person named aside from Jesus and his mother Mary. ${ }^{11}$ This may be taken as a sign of God's judgement on the first century Roman Empire, the responsibility of specific political rulers, or the contextual

8 (Hovey and Phillips 2015, p. 55). Noting the distinctions and similarities among this German tradition of political theology narrowly conceived, public theology, and liberation theology, Hak Joon Lee, argues that "political theology and liberation theology tend to give more weight to the state than to civil society as the primary locus (or instrument) or social change" (55). We will see this is not the case for political theology in the broadest sense.

9 See (Lloyd 2012). And forthcoming Ruben Rosariao-Rodriguez's Introduction in (Rosario-Rodriguez 2019). Here Rosario-Rodriguez notes that "What unites the project, despite the diversity of theological perspectives, is a commitment from all the contributors to engage the political sphere (1) by locating him or herself theologically within the interdisciplinary conversation, (2) by establishing clear methodological parameters for how she or he will participate in the conversation, and (3) by recognizing that this conversation takes place in a religiously and politically pluralist global setting." For him, the third point about plurality is crucial. "Without denying that certain religious perspectives make exclusivist claims," he continues, "these claims must be made and defended in the context of political pluralism, tolerance, and cooperation" (xxi). Political theologians should recognize and tolerate plurality even as they advance arguments specific to their own interpretation of their traditions.

10 See (Lloyd 2012; Bretherton 2019).

11 (Bretherton 2019, pp. 18-19; Taylor 2011; Coakley 2013, p. xvii). See Coakely's description of theologie totale (xvii ff) 
nature of the incarnation. In any case, the early creeds seem to display the inherently political nature of theology. Political theology in the broadest sense includes this vast legacy-from the Exodus and wilderness story of the Hebrew Scriptures, which have become central to much liberation theology, to the kingdom of God (Basileia tou Theou) of the New Testament scriptures, and from third-century martyrs of the Roman Empire, such as Perpetua and Felicity, to nineteen and twentieth-century martyrs of American Empire, including enslaved persons, Civil Rights protesters, and Oscar Romero among countless and nameless others.

In these broad senses, Protestant theology extends an ancient theological legacy that is inherently political, as well as theological reflection on politics external and internal to the church itself. After all, Protestant theology was birthed in a movement of protest against certain forms of institutional power, ecclesial authority, and hierarchical arrangements and developed a range of alternative church polities. At the same time, it has been deeply intertwined with - at points aiding and abetting, ignoring, or criticizing, but always in relation to-the modern blight of colonialism and the Black Atlantic. ${ }^{12}$ As one instance of a politics of tending, some Protestant theologians emphasize the importance of attending to this history, to liberation theologians, and to a variety of lesser known theological voices from the underside of history alongside magisterial and radical reformers. ${ }^{13}$ Protestants have built on pre-modern theological legacies, by articulating a range of positions in political theology: Augustinian/Reformed and Aristotelian/Thomistic, confessional and non-confessional, sapiential and apocalyptic, and with a focus on moral reform and socio-political reform. Some have sought to reconcile approaches that have often been set at odds, such as Augustinian and Thomistic accounts. ${ }^{14}$ Others who embrace this reconciliation attend to more radical traditions that tend to be ignored when classical distinctions become primary.

Not all Protestants identify with political theology in any of these senses. In "How (Not) to be a Political Theologian," Stanley Hauerwas, one of the most prominent contemporary Protestant theologians, characteristically avoids the phrase "political theology" and resists the epithet "political theologian" for himself, endorsing instead what we might call a politics of refusal. ${ }^{15}$ And yet, he does so for the same reason others use these terms. Like Bretherton, Taylor, and Coakley, he assumes that "every theology, even theology done in a speculative mode, has been produced [by] and reproduces a politics." Following the post-liberal theological emphasis on Christian terms and narratives, he prefers the term "theological politics" to "political theology." The latter, exemplified by Jorgen Multmann, he thinks, attempts to "theologize over a politics that already exists." Conversely, theological politics, exemplified by Bonhoeffer, he claims, refuses this approach and begins instead by asking about the community that embodies these claims. ${ }^{16}$ Faithful witness is a matter of faithfulness to the politics Jesus incarnated. According to Hauerwas, this will entail something like James C. Scott's account of anarchy, an "exercise in small politics," in which the church acts primarily through episodes of "foot-dragging and disruption" - a politics of refusal par excellence. ${ }^{17}$ He seeks to hold this call for episodic disorder in tension with the claim that "the church is rightly a hierarchical institution ... because the church is a community that believes the truth matters" (190). Exactly what kind of hierarchy, and what

12 (Gilroy 1993; Jennings 2011).

13 See (Jennings 2011; Bretherton 2019, pp. 23, 26, ff).

14 (Bretherton 2019). See Bretherton's first chapter for an excellent overview of these various distinctions and adherents to each. For an account that seeks to blur prevalent distinctions between Augustinian and Thomist accounts see (Gregory and Clair 2015, pp. 176-95).

15 (Hauerwas 2015b, p. 171). All references in this paragraph come from this chapter unless otherwise noted. For more on the extent to which Hauerwas identifies as a Protestant theologian see: (Hauerwas 2017).

16 (Hauerwas 2015a, p. 34; Rasmusson 1995). It is not precisely clear what this distinction amounts to in the essay itself. Nor do I seek to clarify the muddy water here. Of course, it resembles a similar priority of theology-first politics found, at times, in Karl Barth. Gary Dorrien's description of Barth's theology to politics and his conflicts with friends and colleagues over these, could nearly apply to Hauerwas. (Dorrien 2019, p. 267).

17 (Hauerwas 2015b, pp. 186-88). 
this hierarchy has to do with the truth or with the politics of Jesus, and what each have to do with foot-dragging, he does not say.

Hauerwas here presents a two-fold politics of refusal. On the one hand, he refuses the term "political theology" even as he agrees with those, like Bretherton, who see the inherently political nature of theology. On the other hand, his theology of the church as foot-dragging appears akin to other forms of what Molly Farneth has called a "politics of refusal" rather than, to borrow Sheldon Wolin's term, a "politics of tending." ${ }^{18}$ Hauerwas might object that foot-dragging is precisely the sort activities he endorsed as a "politics of tending" or form of radical Christianity in Christianity, Democracy, and the Radical Ordinary. ${ }^{19}$ Yet, here as there, this form of foot-dragging appears aimless, that is aimed at no specific goods or ends, intent only on disruption and disorder. ${ }^{20}$ Absent the specification of aims and the virtues needed to pursue them, the activity of foot-dragging may be salutary or nefarious. Other twenty-first century theologians-from Luke Bretherton, John Bowlin, Eric Gregory, and James K. A. Smith, to Willie Jennings, James Cone, Emilie Townes, Katie Cannon, Kelly Brown Douglass, Traci West, Kwok Pui Lan, and Shelly Rambo, among others-have made significant contributions to politics of tending and organizing to attain specific ends and shared goods, however provisional. ${ }^{21}$ A debate remains among Protestant political theologians, broadly conceived, about whether the politics of Jesus call primarily for a politics of refusal, foot-dragging, and disruption, or instances of these as one aspect of tending, organizing, and a broader spectrum of political participation. The rest of this essay attends to some of these theologians who contribute to this debate.

\section{Plurality}

Brad Gregory's The Unintended Reformation resembles other prominent declensionist narratives about modernity, most explicitly Alasdair MacIntyre's After Virtue, while focusing on the unintended implications of the Protestant Reformation. The problem, in Gregory's account, as we considered at the outset, is at least two-fold: 1 . The Reformation replaced the ethics of virtue, which gave cohesion to the notion of the common good, with a secular ethics of rights, and 2. what he calls "hyperpluralism" has made it nearly impossible to adjudicate competing claims about goods, let alone common goods. The Reformation ushered in not the kingdom of God on earth, but "the kingdom of whatever."22 I address the first point below. Here, I seek to nuance and challenge aspects of Gregory's account of Protestantism, "hyperpluralism," and their effects in modernity as well as protestant anxieties about pluralism.

The narratives of modernity's despisers produce a politics of refusal. They conceive of the pluralism of modern politics as "civil war carried out by other means." ${ }^{23}$ Denounce modernity as a moral wasteland of pluralism, subjectivism, and secularism, and a politics of refusal-to participate, tend to shared goods, or organize on their behalf-appears the only reasonable or faithful way forward. In After Virtue, MacIntyre famously tells a story of modern decline and waxes nostalgic for better times. Gregory's story, while less nostalgic, is one of resentment. He begrudges the loss of a unified institutionalized Christendom and worldview of the medieval era, which he finds necessary for the cultivation of the virtues and faithfulness to Jesus Christ. His primary concern with modernity is not religious pluralism broadly, which has always been more and less a feature of shared life (a point he

18 (Farneth 2019). Scott's form of anarchy and Hauerwas's foot-dragging depend on institutions being in place independent of and prior to episodic disruption. Throughout the chapter, Hauerwas appears to be entirely ambivalent about the form of government or institutions in relation to which the church does its foot-dragging. Of course, the church must be the church in any political context. But I find it hard to believe that Hauerwas would not actually prefer a democratic republic and society like the United States of America (for all its shortcomings) over other totalitarian states as the political context for politics of refusal. The projects of John Milbank and Oliver O'Donovan evince a similar refusal.

19 (Hauerwas 2008).

(Bowlin 2011).

1 See for example (Pui-lan 2016, pp. 223-25).

22 (Gregory 2015, p. 112). All of the following citations from Gregory are from this work unless otherwise noted.

23 (MacIntyre 2007, p. 253). 
downplays) but rather the intra-Christian plurality of views, doctrines, institutions, and authorities that Protestantism occasions (100). These forms of Protestant plurality are undeniable (a central theme of this essay). Nonetheless, Gregory's account conceals the disputes about authority and papal office within the Catholic church that long predate the formal split with Reformers, as well as the plurality of views about the big "Life Questions" internal to the Catholic church to this day. Put differently, the Protestant Reformation represents an institutionalization of Christian plurality that was already and still is present in other ways. ${ }^{24}$

Similar anxieties appear to motivate protestant criticisms of pluralism external to the Christian tradition or what Hauerwas has called the "ideology of pluralism." In early works, such as Resident Aliens and "Preaching Like We Still have Enemies," he argues that pluralism in theology, specifically that of H. Richard Niebuhr's Christ and Culture, "became an ideology for justifying the alleged pluralism of American culture ... . Liberal theology gave a theological rationale for liberal democracy." ${ }^{25}$ In contrast to MacIntyre's image of civil war, this protestant pacifist suggest that pluralism is a nefarious peace treaty. Rather than having the courage to engage conflicts and debates, "we have comforted ourselves with the ideology of pluralism, forgetting that pluralism is the peace treaty left over from past wars that now benefits the victors of those wars." 26 The claim reflects Gregory's concern about subjectivism, relativism, or the "kingdom of whatever." But it further suggests that pluralism is somehow the mantra of victorious warlords rather than victims of intra-religious, even intra-protestant conflict, persecution, and domination. This odd claim does not bear out in the case of the dissenters, as we will see. And yet in a recent review of Rowan William's Faith in the Public Square, Hauerwas appears more ambivalent. He has abandoned the language of the "ideology of pluralism." 27 Here, rather, he admits that in spite of his long-standing criticism of rights language he finds William's account of rights persuasive, as well as presumably his defense of pluralism and "argumentative democracy," each of which draws on his account of the body. ${ }^{28}$ If tending to the body reflects a turn from a politics of refusal to that of tending it is certainly most welcome.

I agree then with Hauerwas, Gregory, and Jennifer Herdt that, in Herdt's words, "modern pluralism makes impossible a fully institutionalized (in Charles Taylor's terms, embedded) worldview, a faith that is embodied in a comprehensive way across all social practices and institutions." ${ }^{29}$ But I doubt several of the conclusions that Gregory (and to some extent Hauerwas) thinks follow-namely the secularization, individualism, and subjectivism of our current moment and the impossibility of working toward shared common goods.

I take religious and moral pluralism, or what Gregory calls "hyperpluralism" (however one measures degrees of pluralism), to be a fact of life in all times and places, even if modernity has multiplied the range and frequency of interactions among different faith communities. But there is considerable dispute about whether these other "isms" come packaged with pluralism. I return below to the secularization thesis, which has been largely discredited. ${ }^{30}$ As for individualism, subjectivism,

24 See Jennifer Herdt's perspective response to Gregory's book. (Herdt 2016). I agree with Herdt that, “Protestantism may have made the issue [of competing views and authorities] more salient, more present to ordinary people throughout Europe. But it did not create the problem of crises of authority, or of rival answers to the big "Life Questions" (587). Still, I would add that Protestantism did not only "make the issue more salient" - it did so by formally challenging the claim that such debates and doctrinal disputes could only be adjudicated by the institutional authority of a single church. While it did not create the problem of the crises of authority, it did provide a very different set of answers, institutions, and polities in response to the crises of authority. One crucial part of that response includes the conviction that authority cannot only be adjudicated or mediated by the institution of the church alone, but depends a community with a priesthood of all believers. (Hauerwas and Willimon 2014, p. 41).

26 (Hauerwas 1995).

27 (Williams 2015). See especially Chapter 10 entitled "Pluralism: Public and Religious."

28 (Hauerwas 2013). He finds compelling the idea that "the body is not simply one object among other objects, and therefore, should not be used as an instrument for imposing my will on others."

29 (Herdt 2016).

30 The secularization thesis—-the idea that traditional religions are in terminal decline in the industrialized world and that as modern societies progress religion loses its authority in all aspects of social life and governance-was a central debate in the sociology of religion in the second half of the twentiety century. 
and relativism, it is not clear that these characterize our contemporary moment, nor that they are the unintended effects of post-Reformation plurality. Take, for instance, the protestant emphases on sola scriptura, the "priesthood of all believers," and continuing revelation. These do not always or typically entail, as Gregory fears, that authority resides solely in the interpretations of individuals or in subjective beliefs, rendering all truth claims relative. Rather, these emphases tend to shift the locus of authority onto communities of interpreters of scripture who are accountable to one another (in various ways depending on the ecclesial polity) as well as to the tradition of Christian interpretation and reflection. ${ }^{31}$ The differences among Protestant denominations were, and are to this day, as we will see in the example of the dissenters, based on the convictions of interpreting communities, which do not hold truth claims to be merely subjective. The same can be said of other faith communities, and social groups, namely that an acknowledgement and even celebration of intra-Protestant or religious pluralism does not amount to the idea that truth claims are entirely relative or subjective. Indeed, the dissenting claim that all faith communities in a religiously plural society have rights to the freedom of religious assembly and practice is not merely subjective. It makes a claim on others. Citizens of pluralist societies can collaboratively pursue the proximate shared goods of a common life- goods that contribute to what Augustine calls earthly peace-in the midst of religious, moral, cultural, and institutional diversity. ${ }^{32}$ The civil rights movement in the U.S. serves as one instance, of the pursuit of shared goods in the midst of religious plurality; the dissenters provide another. Indeed, British dissenters and Catholics, both persecuted minorities in eighteenth-century Britain, often joined forces to advocate for religious tolerance.

So too, for other Protestant theologians and ethicists and secular allies, including Herdt, Bowlin, Williams, Smith, Bretherton, Rosario-Rodriguez, and Stout, religious and moral pluralism is not an ideology to be avoided or a proposal to be defended. It is a fact of life, more and less conspicuous in all times and places. This fact leads each of them in different ways to support a politics of tending and organizing rather than refusal. Stout in Democracy and Tradition affirms a Rawlsian "modus vivendi" pluralism as an attempt to articulate a form of pluralism that "citizens with strong religious commitments can accept and that welcomes their full participation in public life without fudging on its own premises." ${ }^{\prime 33}$ And yet, because it is a fact of life, pluralism is not, Stout clarifies, something we merely "settle for," absent more robust social contracts or communitarian unity. We can respond well to this fact by tending well to others who differ from us in beliefs and commitments. Indeed,

31 (Gregory 2015, p. 87). For this reason it is not, as Gregory claims, ironic that Martin Luther would cite Jean Gerson and Augustine as authorities to substantiate his point that "No faithful Christian can be forced beyond the sacred scripture, which is nothing less than [porprie]] divine law ... " Luther understood that the foundational importance of scripture is not at odds with but rather depends on a tradition of Christian interpretation and theological reflection. Likewise, while the priesthood of all believers tends to emphasize the unmediated access of each believer to God, still depends on the respective polities and ecclesial forms of accountability. Even at its most extreme, the doctrine does not generally entail the endorsement of subjective beliefs, or the relativity of all truth claims, but rather the access each individual may have to God's revelation.

32 (Augustine 1998, chp. 17). Many scholars have noted this famous passage in Book 19 that "even the heavenly city, therefore, while in its state of pilgrimage, avails itself of the peace of earth, and, so far as it can without injuring faith and godliness, desires and maintains a common agreement among men regarding the acquisition of the necessaries of life, and makes this earthly peace bear upon the peace of heaven." And yet Augustine's emphasis on plurality of languages, laws, manners, and institutions that all have their proximate end in earthly peace in the passages directly prior to this one is also particularly notable. "This heavenly city, then, while it sojourns on earth, calls citizens out of all nations, and gathers together a society of pilgrims of all languages, not scrupling about diversities in the manners, laws, and institutions whereby earthly peace is secured and maintained, but recognizing that, however various these are, they all tend to one and the same end of earthly peace. It therefore is so far from rescinding and abolishing these diversities, that it even preserves and adopts them, so long only as no hindrance to the worship of the one supreme and true God is thus introduced" (emphasis mine).

33 (Stout 2004, p. 296). Stout is quick to clarify that, "I see this pluralism primarily as an existing feature of the political culture, not as a philosophical doctrine needed to be imposed on it." Oddly enough, Hauerwas in his response to the book claims that "[Stout] affirms pluralism. And it's not clear to me he really knows what he's talking about when he says the word "pluralism." I take it that despite where you're standing, to be able to know that we live in a pluralist world is already part of the problem of naming pluralism" (Springs et al. 2010, p. 430). This is an odd claim given Stout's explicit treatment of the term, in which he clarifies what he means by the word. The onus appears to be on Hauerwas. And is it not so? One could believe in monism and still recognize moral and religious pluralism. 
the alternatives are bleak. ${ }^{34}$ Bowlin, in Tolerance Among the Virtues, helps us to consider the virtues of tolerance and forbearance, among others, needed to tend well to objectionable differences, and so live well amidst plurality. ${ }^{35}$ It is worth lingering here as Bowlin's account of tolerance undermines Gregory's insinuation that the pre-modern virtues have been replaced by modern semblances.

Gregory worries that the central social virtue of modernity is tolerance- "the subjectivization of morality demands it" (232). While liberalism promotes "the maximization of individual choice" the virtue of tolerance promotes the toleration of others "choices and actions," in short the kingdom of whatever (184). But according to Bowlin's Thomistic and Wittgensteinian account, the virtue of tolerance perfects our response to objectionable differences, and does not entail the act of tolerating whatever choices others make. Given the fact of pluralism, according to Bowlin, citizens of modern democracies need to discern which differences are objectionable and which are not. Among objectionable differences, they must distinguish which are tolerable, and which require a different response, such as contestation, coercion, constraint, expulsion, or withdrawal. Membership in any moral, political, scholarly, or ecclesial community requires this discernment this tending to difference. Someone seeking a definitive list of tolerable and intolerable actions, views, or policies will search in vain. All such lists are contingent and open to revision. Bowlin provides examples: from the Civil Rights era $(66,132 \mathrm{ff}$.$) to Uncle Halvor's$ unsavory bigotry at holiday dinners (120), from his son's taste in music $(130-41,239)$ to the Cockfights at the Collinsville Game Club (242-49). His examples are splendid, but they are not our own. The task before us then is to exercise the virtue of tolerance in light of the objectionable differences we face in our own time and context, given our own roles and responsibilities.

Tolerance is one among many of the virtues needed to tend well to the differences that reside in pluralistic societies, and not only in modernity. Because tolerance is a natural virtue that comes packaged with our humanity, it perfects human beings in all times, places, and societies, modern and premodern alike. How should we respond to the facts of pluralism, to the differences-ethical, religious, political, sexual, racial, and ethnic - that characterize our shared life? Justice does not demand in every instance acts of tolerance, and certainly not the blind toleration of any actions and views whatsoever. Resentment about tolerance tends to result from confusing the act with the virtue. Bowlin, rather, argues that the virtue of tolerance, enables citizens to tend well to their differences, to respond to certain objectionable differences with patient endurance as justice demands and so enjoy the common goods of relationships set right, of giving another their due (95). As such, tolerance, like love and justice, is a common good of all political communities. Citizens share it common or not at all. Considering tolerance as a true, indeed natural, virtue, inspires hope rather than resentment in the face of pluralism. Far from Gregory's fears about tolerance ushering in a "kingdom of whatever," in Bowlin's protestant Thomistic account, tolerance and its siblings, natural and theological forbearance, perfects Christians for just and loving participation in inevitably diverse polities they inhabit. Rather than a politics of refusal, Bowlin offers a politics of attentive, patient, even long suffering and sacrificial, participation.

\section{The Secular}

Modernity's religious despisers, such as Brad Gregory, fault not only Protestant plurality, but "the secular age," or the supposed secularization that followed the Reformation, with many of our modern ills. Gregory laments, for instance, that modern moral philosophy has not only "failed to stem the subjectivization of morality rooted in the Reformation; it has augmented it in a secular, rationalist register." 36 The irony, he thinks, is that early modern disagreements among Protestants led "through the right of religious freedom itself to the secular, open-ended expansiveness of rights today as 'deified

34 (Smith 2017). I take Williams's "interactive pluralism” and James K. A. Smith's attempt to move beyond "principled pluralism" to signal a similar acceptance and even affirmation of the fact of pluralism.

35 (Bowlin 2016).

36 (Gregory 2015, p. 220). 
preferences' or as 'an unchecked wish list ... of conflicting subjective wants.'"'37 The irony, by these lights, is three-fold: the rights of religious tolerance and freedom of religion led to the right to reject religion altogether, to the reduction of rights to ostensibly secular conflicting subjective preferences, and to the right to live in ways antithetical to Christian morality and specifically "traditional sexual morality" (187). This is not the place to examine each of these claims in depth. Nonetheless, each point seems much less ironic when one considers that Protestants, like the dissenters, who articulated a Christian account of rights, such as religious freedom, did so because they understood that in pluralist political communities certain freedoms, even the right to unbelief, are higher goods than trying to coerce belief or conformity to so-called Christian morality. At least, this seems to be one of the enduring lessons from the horrors of the colonial era. We are left to wonder which rights are specifically secular (and where the movements for women's rights and civil rights fit in this narrative), whether or not the modern era was in fact secularized in the ways feared, which ways of life are "antithetical to Christian morality," and what "Christian morality" might mean given the plurality of not only non-religious, but Christian views, Protestant and Catholic alike. The greatest irony may be that rights like religious freedom which united British Catholics and Protestant dissenters in a time of shared persecution, has in less harsh times (dare we say due to the enjoyment of those rights under a secular state) united them in a politics of refusal.

The secularization thesis-the idea that traditional religions are in terminal decline in the industrialized world and (or) that as modern societies progress religion loses its authority in all aspects of social life and governance-has been thoroughly challenged, some would say entirely discredited, in the twenty-first century. This should cause us to question grand narratives that give it a central and undisputed place. It is not only that we now live in what some are calling a "post-secular" age, but that as Rodney Stark and Roger Fink argued two decades ago, "it seems time to carry the secularization doctrine to the graveyard of failed theories." 38 So too Peter L. Berger, one of the foremost proponents of secularization during the 1960s, has recanted his earlier claims: "The world today, with some exceptions...is as furiously religious as it ever was, and in some places more so than ever. This means that a whole body of literature by historians and social scientists loosely labeled 'secularization theory' is essentially mistaken." ${ }^{39}$ The claim that secularization in this sense, was and is a mistaken theory, is distinct, of course, from the idea that many states are formally secular, meaning that they have no formal ties or favor with one religion or another. Anxieties about the secular, among Protestants, tend to arise from the worry that secular states that welcome religious plurality, inevitably lead to secular societies which relegate religious practices and reasons to the private rather than the public sphere. ${ }^{40}$

Rowan Williams resists this anxiety, distinguishing between procedural and programmatic secularism. ${ }^{41}$ Procedural secularism entails "a public policy which declines to give advantage or preference to any one religious body over others." ${ }^{\prime 2}$ It is the principle by which the state seeks to

37 (Gregory 2015, pp. 187-88).

38 (Stark and Finke 2000, p. 79). They claimed that it is time to bury the secularization thesis: "After nearly three centuries of utterly failed prophesies and misrepresentations of both present and past, it seems time to carry the secularization doctrine to the graveyard of failed theories, and there to whisper 'requiescat in pace.'” Conversely, Herdt agrees with Gregory that the process of secularization in modernity was largely unintended, but insists that we now live in a post-secular age. (Herdt 2016, p. 601; Taylor 2007).

39 (Berger 1999, p. 2; Stark and Finke 2000, p. 79); So too see Norris, especially chapter 1, for an overview of secularization debates. (Norris 2011).

40 (Springs et al. 2010, p. 430). Similar anxieties about plurality, subjectivism, and secularity, understood as the way that democratic politics keep "out of public discussion matters that matter exactly because they matter, and represses such conflict," particularly religious matters, have long animated Hauerwas.

41 (Williams 2015, pp. 2-3). Williams distinction between procedural and programmatic echoes the one that Charles Taylor has recently drawn between two basic notions of secularism —one that that seeks to regulate and control religion and limit the role of religious discourse in public, and the other that seeks to preserve the space for religious or theological difference and plurality. He advocates for the latter. See his chapter "How to Define Secularism" in (Stepan and Taylor 2014). See also Akeel Bilgrami's response in the following chapter "Secularism: Its Content and Context," where he offers three defining characteristics of secularism before suggesting that its merits depend on the context.

42 (Williams 2015, p. 2). 
keep the peace in a diverse society, made up of various religious communities, without requiring any specific public confession from its public servants or citizens. This form of secularism, Williams argues, is not only compatible with Christian faithfulness, but is likely a result of the early Christian distinction between two kinds of loyalty to two distinct corporate bodies- to the community of faith, on the one hand, and to the political community, on the other. In William's view, this pluralist ideal and view of secularism is in keeping with Augustine, Aquinas, and Karl Barth's call for the church to be an "unreliable ally" for any and every political system. ${ }^{43}$ Notice, calling the church to be an "unreliable ally" is distinct from "foot-dragging" and a principled politics of refusal. Allies tend to one another and organize in pursuit of shared goods. They do so only insofar as they share common ends and goals such as ending oppression and domination, loving one's neighbor, and honoring the human dignity (imago dei) of each person regardless of race, creed, or sex. As an ally, the church must be unreliable because it must always be prepared to oppose any political system or leaders that become corrupt and unjust and so fail to seek such goods.

Alternatively, what William's calls "programmatic secularism" does pose a threat to Christians and to all religious adherents. It is a policy or principle which depends on a strict distinction between private and public spheres and the kinds of discourse that belong in each. It demands that all personal or religious beliefs be kept in the private realm and out of the supposedly neutral or "naked public square" and that public loyalties take precedence. The problem with secularism, so understood, is that it asks citizens to treat their deepest convictions as though they are matters of mere personal preference that should have no bearing on public life; it dilutes moral discourse; it threatens the very plurality that makes procedural secularism vital; and makes public criticisms of the state more difficult, while weakening the imagination needed for radical social change (3-4). It is this latter exclusivist notion of secularism—one that creates and demands a neutral public space- that Protestant political theologians have long and rightly rejected.

Given the proliferation of theories of the secular, it may help to distinguish the theological use of the term from the more familiar philosophical and sociological use of the term "secular." The latter, as we have seen, is typically used to describe a non-religious, anti-religious, or religiously neutral modern age, state, public square, or institution. ${ }^{44}$ In theology, the secular, from the Latin saeculum, has been used to signify the worldly or temporal realm as opposed to the eternal or eschatological. In Augustine's use of the term, this means that human history simply is secular-non-eternal, prior to the eschaton. According to the Augustinian, Robert A. Markus, in his text of that title, the saeculum refers to "the sphere of human living, history, society, and its institutions, characterised by the fact that in it the ultimate eschatological oppositions, though present, are not discernible." 45 For Bretherton, the theological notion of the secular means that all of human history, the premodern no more or less so than the modern, is a field of wheat and tares. ${ }^{46}$ Politics in the modern age, as in all others, is about enabling a limited, shared, earthly peace amid a plurality of religious and moral commitments and communities. In Resurrecting Democracy, he shows how the practices of broad-based community organizing (BBCO) birthed by Saul Alinsky enable diverse communities to carve out what he calls a "faithfully secular" space for mutual exchange. Here, we find a politics of tending to the inevitable differences in pluralist societies wed to a politics of organizing across lines of difference for shared goods. By these lights, protestant should affirm secular society in the institutional sense, which preserves a

43 (Williams 2015, p. 4).

44 Secularism remains a much-disputed concept. Akeel Bilgrami argues that it is value neutral in the sense that its value depends on the ends sought in a specific context. Others, such as Hauerwas, reject the secular as inherently adversarial toward Christianity or exclusionary and opposed to religious views. While still others, such as Jocelyn Maclure and Charles Taylor, argue that secularism, properly understood, is essential to any liberal democracy and may offer the only path to religious and philosophical freedom. Of course, precisely how secularism should be "properly understood" is at the heart of these debates. (Maclure et al. 2011; Hauerwas 2010; Springs et al. 2010; Bilgrami 2014; Mathewes and Nichols 2008; Gregory 2015).

45 (Markus 1989, p. 133).

46 (Bretherton 2019, p. 194). 
space for conversations about proximate goods among diverse persons, groups, and faith communities. How we might do so leads naturally to questions of democracy.

\section{Democracy}

Again, with regard to the merits or demerits of democracy, modernity's despisers, Catholic and Protestant alike, unite in a politics of refusal against "Western liberal democracy," which terms they tend to presume come prepackaged together. ${ }^{47}$ Brad Gregory laments that the "essence of contemporary, Wester liberal democracy" as a "putatively neutral state, is to enable and protect individual rights to divergent preferences." 48 Hauerwas's views of democracy have changed over time in certain respects. Yet they consistently animate politics of refusal. At his most antagonistic, he joins, what Stout, in Democracy and Tradition, calls the "new traditionalists." They associate democracy with liberalism and pit both against the values of the Christian narrative and community. ${ }^{49}$ Because much of his work has been overtly antagonistic toward democracy, Christianity, Democracy, and the Radical Ordinary, where embraces "radical democracy" and "radical Christianity," may seem to signal a revolution. And yet, we have already seen that this form of radical democracy, intent on disruption and disorder, is not dissimilar from his recent advocacy for "foot-dragging." More recently Hauerwas has conceded that Stout's account of democracy as the institutionalization of practical reason is quite persuasive. ${ }^{50}$ Still, noting Niebuhr's quip that "democracy is the worst form of government, aside from all of the others," Hauerwas, himself does not seem convinced. ${ }^{51}$ His call to Christian foot-dragging or anarchy regardless of the form of governance remains.

Conversely, Protestant theologians, ethicists, and activists-from Karl Barth to Martin Luther King Jr., each of whom (despite their differences) supported a vision of democratic socialism-have devoted considerable thought to the forms of political governance and societies that might best achieve earthly peace, sustain socio-political reform, and enable a variety of communities, including Christian communities, to flourish. ${ }^{52}$ Cornel West shares Stout's worries that in castigating modernity, democracy, and liberalism, the new traditionalists fail to recognize the fragility of democracies, the moral substance and efficacy of fellow-citizens, and what it takes to sustain the legacy of Martin Luther King Jr. and his secular allies..$^{53}$ The virtue of piety provides a remedy. Whereas Sheldon Wolin claims that we're living in a postdemocratic age, an "inverted totalitarianism" driven by commodification, Stout makes, in West's words, the "democratic wager that the demos has what it takes to sustain the democratic experiment ... a Pascalian wager on the plebs." ${ }^{\prime 54}$ Stout's book, Blessed are the Organized, provides a portrait of the work of the Industrial Areas Foundation (IAF)—a citizen led, Broad Based Organization in the tradition of Saul Alinsky-in the aftermath of the Katrina hurricane in New Orleans. ${ }^{55}$ The organizing work of IAF, a model of the kind of work that sustains democracies, helps to sustain Stout's hope in the democratic experiment. Hope is not so much a wager as a virtue that resists the vices of presumption and despair-both of which appear to animate the various politics of refusal.

47 (Springs et al. 2010; Gregory 2015, p. 78).

48 (Gregory 2015, p. 78).

49 (Springs et al. 2010, p. 430). In response to Stout's book, Hauerwas confirmed his fear that "Democratic politics is so adept at keeping out of public discussion matters that matter exactly because they matter, and represses such conflict." As with pluralism and secularism he is concerned that democratic politics relegate the matters that matter most-religious beliefs, claims, and practices-to the private realm. Yet, this presumption runs explicitly against Stout's argument for democracy and pluralism (as seen above) which seeks to create space for productive contestation across lines of religious and non-religious difference.

(Hauerwas 2015b, 15 n. 8).

Hauerwas, 177.

(Dyson and Jagerman 2000, p. 78; Dorrien 2019).

(Springs et al. 2010, p. 416).

(Springs et al. 2010, p. 418).

(Stout 2010). 
Bretherton, who offers a distinctively Protestant vindication of democracy, shares this hope. In Resurrecting Democracy, he examines and extols the work of London Citizens, an IAF organization in the UK. In Christ and the Common Life, he provides a political theology that makes the case for a Christian commitment to democracy - which has as much to do with the everyday participation of citizens as the "modern liberal democratic state." ${ }^{16}$ While he considers the resources that humanism, Black power, Pentecostalism, and Catholicism each have to affirm democracy, he identifies with the tradition of Anglican Political Theology (APT). ${ }^{57}$ Richard Hooker and Samuel Taylor Coleridge are founding figures of APT, but it was John Neville Figgis (1866-1919) who laid the groundwork for the consociational position that Bretherton commends. As an alternative to the social contract tradition of John Locke, the consociational approach relies on an ad hoc commensurability between different visions of the good and on common objects of love, which generate the contingent basis for common life. According to this pluralistic vision of sovereignty, "the role of the state is to uphold the rule-bound, accountable, and equitable arena of earthly peace that enables the negotiations of a just and merciful common life between diverse communities. ${ }^{\prime 58}$ Christians need not share metaphysical commitments with one another or with other faith traditions to participate in this vision and to contribute to the shared proximate goods of earthly peace and flourishing. The virtues—of piety, faith, hope, love, tolerance, and courage, among others-are crucial for sustaining this vision of democracy and the shared goods of our common life.

I have focused to this point on late twentieth and early twenty-first-century debates among Protestant political theologians who commend a politics of refusal, on the one hand, and a politics of tending and organizing for shared goods, on the other. The latter have a precedent in the eighteenth-century British dissenters and non-conformists at the inception of modern democratic experiments. Here we will see that at the very moment that supposedly led to the eclipse of an ethics of good and virtue with a secular ethic of rights, the dissenters contend that true virtues and rights are both shared goods of ethically, religiously, and theologically diverse democratic societies.

\section{The 1790s to the 1970s: For the Love of Country, Neighbor, and Stranger}

In short, modernity's despisers, Protestant and otherwise, argue that modernity renders common goods obsolete. ${ }^{59}$ Our modern condition, they say, is one of hopeless pluralism and intractable moral disputes. They mark "the modern" at the infamous inception of the French Revolution-the ill-fated date of 1789. According to Gregory's story, one significantly indebted to MacIntyre, modernity entails a transition from "a Christian ethics of the good [and virtue] to a secular ethics of rights" and a concomitant inability to adjudicate between rival moral claims (179). Many examples might be invoked to challenge this narrative: from the nineteenth-century British and German Romantics to American Transcendentalists and Pietists, and from twentieth-century movements for women suffrage and civil rights to the womanist ethics of Katie Cannon. ${ }^{60}$ I focus here on a specific cast of eighteenth-century characters-namely Mary Wollstonecraft and religious dissenters such as Richard Price and Anna Barbauld - because they shed a different light on the revolution debates of the 1790s. For the religious or rational dissenters, a divorce between an ethics of virtue and rights, or individual and common goods is inconceivable. The cultivation of the virtues as well as contestation about them, according to these Protestants, are part and parcel of the goods that Christian traditions and democratic societies alike share in common. Wollstonecraft and her dissenting friends understood that virtues such as

\footnotetext{
(Bretherton 2019).

57 (Bretherton 2019, p. 463). And see chapter 6 and p. 175 for a summary comparison of the differences in Pentecostal, Catholic, and Anglican polities as populist, institutionalized, and fluvial respectively.

58 (Bretherton 2019, p. 184). See also p. 161 where he distinguishes this "consociational" vision of sovereignty from "top-down, monistic, and transcendent conceptions of sovereignty."

59 (Bowlin and Latham 2016).

60 (Cannon 2006).
} 
justice and love which set relationships right simply are shared in common or not at all. At the same time, contestation about true virtue and the sexed semblances of Rousseau and Burke, is for this proto-feminist among the shared goods of the democratic and Christian traditions.

The implications of attending to these dissenters is at least three-fold. We find that: 1 . the Reformation did not replace an ethics of virtue with an ethics of rights-according to dissenting political theology, both rights and true virtues are shared political goods; 2 . The ethical conflicts and plurality that characterize modernity-the revolution debates of the 1790s no less than those of the 1970s - may render a mythical or institutionalized common good obsolete, but they do not render subjective or relativize morality, nor do they undermine proximate goods shared in common; 3 . The traditions of Christianity, the virtues, and feminism have always been traditions of dissent. They have always involved a measure of agonism amidst unity-in the pre-modern as in the modern era. Wollstonecraft combines and extends these traditions of dissent in distinctively modern ways for distinctively feminist, democratic, and Christian ends.

Religious Dissent, which has deep roots in the Reformation, received its legislative christening in England's Clarendon Codes, including the Test and Corporation Acts, beginning in $1661 .^{61}$ Their persecuted status under the Church of England led religious dissenters to embrace and radicalize ancient democratic ideals of inclusion, equality, religious toleration, and accountability. The emergence of rights discourse gave them a new language with which to express their political aims such as freedom of assembly, conscience, worship, and representation in government.

Crucially, Wollstonecraft and the religious dissenters did not advocate for rights on the basis of secular Enlightenment ideals. Their theological views, specifically their theological anthropology, informed their advocacy for both rights and virtues. The evolution of Old Dissent in the seventeenth and eighteenth centuries-from the Puritans, to the Presbyterians, Armenians, Socinians, and Unitarians, is fascinating but beside the point here. ${ }^{62}$ For my purposes, what theologically unites religious dissent is more important than what divides it. Their theological anthropology accentuated human goodness and limited perfectibility in virtue. So too, the dissenting circles that shaped Wollstonecraft in Newington Green believed in the radical equality of the sexes made in the image of God, the possibility for all human beings to grow in virtue and perfection, and that virtues perfect our relation to God, self, and others. ${ }^{63}$ These theological beliefs in human equality and perfectibility are central to dissenters' support for rights and virtues alike. ${ }^{64}$

Gregory argues that Protestants either abandoned the virtues altogether or replaced the theological virtue of charity (caritas) with the early modern social virtue of obedience, and finally the modern virtue of tolerance, which he depicts as a semblance. ${ }^{65}$ He does not distinguish, as does Bowlin, between the liberal ideal, the act, and the virtue of tolerance, between the semblance of tolerance as "the kingdom of whatever" and the virtue of tolerance as a perfection of our response to objectionable differences. The Toleration Act of 1688 had granted freedom of worship to trinitarian Protestants who dissented from the Church of England, but not yet to Catholics or unitarians. Tests and oaths that barred the latter from worship, holding public office, keeping schools, and owning land, were gradually rescinded by laws such as the Unitarians Relief Act of 1813 and finally the Test Abolition Act of 1867. In America, the Calvert family which established Maryland, largely as a refuge for British Catholics, had already passed the Maryland Toleration Act in 1649, which became an inspiration and precedent for freedom

61 Penalties against Unitarians were not removed until the Unitarian Toleration Bill (1813).

62 (Daniel 2006)

63 (Price 1830; Barbauld 1825; White 1804).

64 Gregory concedes that rights had a theological inception in the early modern era, but he mourns their secular modern progseny without specifying when this ostensible change occurred.

65 (Gregory 2015, p. 132). 
of religion in the United States. ${ }^{66}$ The British unitarian dissenters certainly joined Catholics on both sides of the Atlantic in advocating for greater tolerance, as a virtue as legislative protection. Yet other virtues, such as candor and the theological virtue of charity among others, remained central to their account of individual and common goods, as well as to their appeal for rights.

The virtue of candor, understood as open avowal or outspokenness, is exemplified in the Revolution Debates of the 1790s. ${ }^{67}$ These debates famously began on 4 November 1789 , when the dissenting preacher Richard Price gave a speech entitled "Discourse on the Love of our Country" to commemorate the 101st Anniversary of the Glorious Revolution (1688). The anniversary came on the heels of the French Revolution. Price celebrates the French Revolution as the Enlightened extension of its British and American siblings.

Given this diffusion of liberty, he addresses the age-old tension between patriotism and Christian cosmopolitanism, between love of country, and universal love of neighbor. The love of country is, he claims, "certainly a noble passion; but, like all other passions, it requires regulation and direction." 68 Like Augustine in the third century and post-colonial political theologians in the twenty-first century, Price knows that the love of country, has too often manifest as "a love of domination; a desire of conquest, and a thirst for grandeur and glory" (8). As a remedy, he turns to Jesus and his Apostles who have "laid such stress on loving all men, even our enemies, and made an ardent and extensive charity so essential a part of virtue, that the religion they have preached may ... be called the Religion of Benevolence. Nothing can be more friendly to the general rights of mankind" (11). Having featured charity as the virtue that perfects love of country and alien or neighbor alike, he considers the parable of the Good Samaritan. This parable provides the crucial counterpoint to excessive love of country-for all people of all nations and religions are included in the dual love command. In a section on virtue he reiterates that virtue includes "the discharge of the public duties of religion" (17). In this dissenting speech, the virtue of charity not only remains central, it provides the justification for Price's account of human rights. The address should help to assuage some of Gregory's anxieties about an ethics of rights versus virtues, the eclipse of charity with tolerance, the privatization of religion, and the subjectivization of morality. The same is true of Wollstonecraft's subsequent Vindications.

If candor is a central dissenting virtue, Wollstonecraft is exemplary. She had become close friends with Price and she leapt to defend the dissenting preacher against Burke's pointed attack in his Reflections on the Revolution in France published a year later, in November of 1790. That same month, she published her Vindication of the Rights of Men, defending not only Price but human rights and the revolutionary cause. Two years later she published Vindication of the Rights of Woman, (1792) the first political treatise to contend for women's rights as human rights. In both Vindications, she advocates for rights not as an end in themselves, not for the sake of individual liberty alone, but rather so that men and women alike might cultivate true virtues, for the flourishing of individuals and the communities they inhabit.

Her account of rights and virtues, like that of her dissenting friends, is informed by her theological imagination of the attributes of God and specifically her theological anthropology. Daniel White is right to describe Wollstonecraft as a non-conforming non-sectarian. ${ }^{69}$ Her own non-conformity is perhaps most clear in her non-sectarian refusal to align herself with any one Christian community.

66 The Toleration Act, as it is now commonly called, allowed freedom of worship and conscience for all Trinitarian Christians in Maryland. Still, it sentenced to death anyone who denied the divinity of Jesus. Religious tolerance and freedom has apparently always had its limits, even if we draw them quite differently today.

67 (Richey 1973). Russel Richey has argued that the history of dissent can be traced through the transformation of the central dissenting virtue of candour, which was expressed in four successive ideals: purity, kindness, open-mindedness or tolerance, and finally open avowal or outspokenness. Thomas Holcroft (1745-1809) fervently believed in human perfectibility. He was tried for and acquitted of high treason in 1794, but continued to remain suspect as a free thinker. Wollstonecraft reviews his novel Anna St. Ives, in the Analytic Review, and notes that it "appears to be written as a vehicle to convey what are called democratical sentiments."

68 (Price 1790, p. 6). Other citations in this paragraph are from the same text.

69 (Daniel 2006). 
Wollstonecraft, like her friend Anna Barbauld, was critical of Rational Dissent for its unaffecting rationalism. Nonetheless, her theological imagination was profoundly shaped by Price and Barbauld and other prominent dissenters. She shares their perfectionist, intellectualist, and eudaemonist theological anthropology as well as their insistence that all human beings possess the image of God. This theology informs her support of the democratic ideals—if not the means or philosophy—she found at the heart of the French Revolution. ${ }^{70}$

Modernity's despisers might be surprised to discover in Wollstonecraft's second Vindication, an ardent defense of women rights for the sake of women's perfection in the virtues, as creatures made to imitate the attributes of God and grow in loving devotion to God and neighbor. But this is precisely what we find. This text is as much a defense of true virtues and a critique of their sexed semblances, as it is an argument for women's rights. Such disparate eighteenth-century luminaries as Jean-Jacques Rousseau and Edmund Burke both propagated a sexually distinct account of the virtues. By these lights, the perfection of males consists in the cardinal virtues of justice, fortitude, temperance and prudence, but for women, as Wollstonecraft notes, "gentleness, docility, and spaniel-like affection are ... consistently recommended as the cardinal virtues of the [female] sex." ${ }^{\prime 71}$ Having roundly criticized these prominent gendered accounts, she declares, "I here throw down my gauntlet, and deny the existence of sexual virtues" (120). Like Augustine, Aquinas, and other social critics before her, she is intent to distinguish true virtues from their semblances. For Augustine, Christian and pagan virtues respectively mark this distinction. But Wollstonecraft, in her clarion call for a "revolution in female manners," insists that her Christian audience distinguish true virtues from their sexed semblances $(14,120)$.

What then of the anxieties about modern pluralism? Do not the Revolution Debates exemplify the very intra-protestant hyperpluralism that Gregory and MacIntyre fear undermine the common good, and specifically Christian good, in modernity? Well, yes and no. They do exemplify intra-protestant pluralism, but not at the expense of common goods. In Wollstonecraft and the religious dissenters, we find that the traditions of the virtues, feminism, democracy, and Christianity, for all their internal plurality, are commensurable. Far from undermining the possibility to pursue common goods, they advance it considerably by advocating for the shared goods of rights and true virtues. Wollstonecraft understood that protest or contestation about the virtues and their sexed semblances, rather than preventing the common good, is of a piece with it. The alternative is unquestioning obedience or acquiescence to established authorities, whether ecclesial or political, however corrupt and corrupting. Price and Wollstonecraft place charity and justice at the center of their accounts of the virtues, human rights, and common goods, extending and radicalizing the pre-modern traditions of the virtues, democracy, Christianity. The dissenters thus challenge the mythical divorce between an ethics of rights and virtues at the very historical moment often used to define modernity.

I have suggested that Christianity, premodern and modern alike, has always been a living tradition of dissent, one marked by some degree of plurality, contestation and agonism in the midst of unity. These intra-Protestant debates about the French Revolution demonstrate that some of modernity's most contested public debates have occurred, not between Protestant and Catholics, or different religious groups, but among adherents of the same traditions. At the same time, Catholics, dissenters, and all manner of persecuted minorities, have found common cause in advocating for the shared goods of religious freedom.

There is much to despise about modernity. Who does not loathe the blood gratuitously shed waging the wars of religion, the indescribable horrors of colonization and the slave trade, the terror of empire at home and abroad, the impossibly sluggish and incomplete recognition of all humans as such, the insanity of the Shoah (Holocaust) and other genocidal campaigns, or the complicity of

\section{(O'Neill 2007).}

71 (Wollstonecraft 1989). All citations from Wollstonecraft that follow are from this source, unless otherwise noted. The fifth volume includes both of her Vindications. 
Catholic and Protestant churches in each? But these are not the primary concerns of the sub-set of modernity's religious despisers discussed in this essay. The ethical pluralism of modernity, which they despise, does indeed render an institutional medieval common good or mythical ethical common good obsolete. Institutional unity is likely a thing of the past. Compete ethical or moral unanimity is likely a myth. Nonetheless, from the eighteenth century to the twenty first, modern pluralism does not thereby undermine the pursuit of proximate goods shared in common, foremost of which include relationships set right by justice and charity. Nor, does such plurality "subjectivize morality," resulting in vulgar relativism, secularism, or skepticism. Indeed, one point of modern rights discourse has been to establish a shared minimal standard for justice, to guard against tyranny, domination, and abuse of power-a point about which, despite other conflicts, most moderns can agree.

We have seen that Protestant political theologians, specifically in the eighteenth and twenty-first centuries, have a plurality of views about pluralism and its merits. We might have considered others: liberal theologians and pietists in the nineteenth century, Karl Barth, Paul Tillich, Reinhold Niebuhr, John Howard Yoder, James Cone, Katie Cannon, and other mighty dead of the twentieth century. In every century, those committed to a politics of tending and organizing for the sake of shared peace tend to embrace some measure of religious and moral plurality — not as a necessary yet lamentable fact of our modern culture- but as a fact of all polities and religious communities and as a shared good of our common life. ${ }^{72}$ Plurality is not the aim or goal. As for ecumenists who work for ecclesial unity that preserves diversity, the goal is tending to differences and organizing despite them, for the sake of shared goods.

Funding: This research received no external funding.

Conflicts of Interest: The author declares no conflict of interest.

\section{References}

Augustine, Saint. 1998. The City of God against the Pagans. Cambridge: Cambridge University Press.

Barbauld, Anna. 1825. The Works of Anna Lætitia Barbauld. London: Longman, Hurst, Rees, Orme, Brown, and Green, Available online: http://hdl.handle.net/2027/mdp.39015007012860 (accessed on 9 September 2019).

Berger, Peter L., ed. 1999. The Desecularization of the World: Resurgent Religion and World Politics, 1st ed. Washington: Grand Rapids, Mich: Eerdmans.

Bilgrami, Akeel. 2014. Secularism, Identity, and Enchantment. Cambridge: Harvard University Press.

Bowlin, John R. 2011. Just Democracy, Just Church: Hauerwas and Coles on Radical Democracy and Christianity. Scottish Journal of Theology 64: 80-95. [CrossRef]

Bowlin, John R. 2016. Tolerance among the Virtues. Princeton: Princeton University Press.

Bowlin, John R, and Andrew Latham. 2016. Is the Common Good Obsolete? Commonweal Magazine. Available online: https://www.commonwealmagazine.org/common-good-obsolete (accessed on 27 December 2018).

Bretherton, Luke. 2019. Christ and the Common Life: Political Theology and the Case for Democracy. Grand Rapids: Eerdmans.

Cannon, Katie G. 2006. Black Womanist Ethics. Eugene: Wipf \& Stock.

Coakley, Sarah. 2013. God, Sexuality, and the Self: An Essay "On the Trinity". Cambridge and New York: Cambridge University Press.

Daniel, E. White. 2006. Early Romanticism and Religious Dissent. Cambridge Studies in Romanticism. Cambridge and New York: Cambridge University Press.

72 Moral and doctrinal plurality within the church has been a more or less conspicuous fact of the Christian church since its inception, even if the schism of 1054 and the Protestant reformation brought institutional plurality. Bretherton's consociational approach, Kevin Hector pneumatological approach, and Rosario-Rodriguez's liberation and pneumatological approach provide theological warrant for embracing religious, theological, and moral plurality respectively. In addition to Bretherton, see (Hector 2011; Rodríguez 2018). As Ruben Rosario-Rodriguez asks Dogmatics After Babel, "what happens when we stop viewing theological pluralism as a problem to be solved (Babel) and embrace it as a gift of the Spirit (Pentecost)?" $(\mathrm{xiv}-\mathrm{xv})$. 
Dorrien, Gary. 2019. Social Democracy in the Making: Political and Religious Roots of European Socialism. New Haven: Yale University Press.

Dyson, Michael Eric, and David L. Jagerman. 2000. I May Not Get There with You: The True Martin Luther King, Jr. New York: Simon and Schuster.

Farneth, Molly. 2019. A Politics of Tending and Transformation. Studies in Christian Ethics 32: 113-18. [CrossRef] Gilroy, Paul. 1993. The Black Atlantic: Modernity and Double-Consciousness. Reissue edition. Cambridge: Harvard University Press.

Gregory, Brad S. 2015. The Unintended Reformation: How a Religious Revolution Secularized Society. Reprint Edition. Cambridge: Belknap Press: An Imprint of Harvard University Press.

Gregory, Eric, and Joseph Clair. 2015. Augustinianisms and Thomisms. In The Cambridge Companion to Christian Political Theology. Edited by Craig Hovey and Elizabeth Phillips. Cambridge: Cambridge University Press, pp. 176-95.

Harrison, Peter. 2015. The Territories of Science and Religion. Chicago: University of Chicago Press.

Hauerwas, Stanley. 1995. Preaching as Though We Had Enemies|Stanley Hauerwas. First Things. Available online: https://www.firstthings.com/article/1995/05/003-preaching-as-though-we-had-enemies (accessed on 23 May 2019).

Hauerwas, Stanley. 2008. Christianity, Democracy, and the Radical Ordinary: Conversations Between a Radical Democrat and a Christian. Eugene: Wipf \& Stock Pub.

Hauerwas, Stanley. 2010. How Real Is America's Faith?|Stanley Hauerwas: Face to Faith. The Guardian. Available online: https://www.theguardian.com/commentisfree/belief/2010/oct/16/faith-america-secularbritain (accessed on 16 October 2010).

Hauerwas, Stanley. 2013. Review of Rowan Williams's Faith in the Public Square. Theology 116: 119-22. [CrossRef] Hauerwas, Stanley. 2015a. Performing the Faith: Bonhoeffer and the Practice of Nonviolence. Eugene: Wipf \& Stock. Hauerwas, Stanley. 2015b. The Work of Theology. Grand Rapids: Eerdmans.

Hauerwas, Stanley. 2017. After the Reformation: How to Be Neither Catholic Nor Protestant. ABC Religion $\mathcal{E}$ Ethics. Available online: https://www.abc.net.au/religion/after-the-reformation-how-to-be-neither-catholicnor-protestant/10095238 (accessed on 1 November 2017).

Hauerwas, Stanley, and William H. Willimon. 2014. Resident Aliens: Life in the Christian Colony. 25 Exp Anv edition. Nashville: Abingdon Press.

Hector, Kevin W. 2011. Theology Without Metaphysics: God, Language and the Spirit of Recognition. Cambridge: Cambridge University Press.

Herdt, Jennifer A. 2016. Proximate Common Goods in the Context of Pluralism. Journal of Medieval and Early Modern Studies 46: 583-602. [CrossRef]

Hovey, Craig, and Elizabeth Phillips, eds. 2015. The Cambridge Companion to Christian Political Theology. Cambridge Companions to Religion. New York, NY: Cambridge University Press.

Jennings, Willie James. 2011. The Christian Imagination: Theology and the Origins of Race. New Haven: Yale University Press.

Lloyd, Vincent, ed. 2012. Race and Political Theology, 1st ed. Stanford: Stanford University Press.

MacIntyre, Alasdair. 2007. After Virtue: A Study in Moral Theory, 3rd ed. Notre Dame: University of Notre Dame Press.

Maclure, Jocelyn, Charles Taylor, and Jane Marie Todd. 2011. Secularism and Freedom of Conscience. Cambridge: Harvard University Press, Available online: https://www.jstor.org/stable/j.ctt2jbrc0 (accessed on 28 May 2019).

Markus, Robert Austin. 1989. Saeculum: History and Society in the Theology of St Augustine, 2nd ed. Cambridge and New York: Cambridge University Press.

Mathewes, Charles, and Christopher McKnight Nichols. 2008. Prophesies of Godlessness Predictions of America's Imminent Secularization from the Puritans to the Present Day, 1st ed. Oxford: Oxford University Press.

Milbank, John, Catherine Pickstock, and Graham Ward, eds. 1998. Radical Orthodoxy: A New Theology, 1st ed. London and New York: Routledge.

Norris, Pippa. 2011. Sacred and Secular: Religion and Politics Worldwide, 2nd ed. Cambridge: Cambridge University Press.

O'Neill, Daniel I. 2007. John Adams versus Mary Wollstonecraft on the French Revolution and Democracy. Journal of the History of Ideas 68: 451-76. [CrossRef]

Price, Richard. 1790. A Discourse on the Love of Our Country. Boston: Edward E. Powars. First published 1789. 
Price, Richard. 1830. Sermons. London: The British and Foreign Unitarian Association, Available online: http://catalog.hathitrust.org/Record/011530849 (accessed on 15 May 2019).

Pui-lan, Kwok. 2016. Postcolonial Intervention in Political Theology. Political Theology 17: 223-25. [CrossRef]

Rasmusson, Arne. 1995. Church as Polis, The: From Political Theology to Theological Politics as Exemplified by Jürgen Moltmann and Stanley Hauerwas. Notre Dame: University of Notre Dame Press.

Richey, Russell E. 1973. From Puritanism to Unitarianism in England: A Study in Candour. Journal of the American Academy of Religion 41: 371-85. [CrossRef]

Rodríguez, Rubén Rosario. 2018. Dogmatics after Babel: Beyond the Theologies of Word and Culture. Louisville: Westminster John Knox Press.

Rosario-Rodriguez, Ruben, ed. 2019. TET Clark Handbook of Political Theology. London: Bloomsbury Publishing, p. xxi.

Smith, James K. A. 2017. Cultural Liturgies. In Awaiting the King: Reforming Public Theology. Ada: Baker Academic, vol. 3.

Springs, Jason, Cornel West, Richard Rorty, Stanley Hauerwas, and Jeffrey Stout. 2010. Pragmatism and Democracy: Assessing Jeffrey Stout's Democracy and Tradition. Journal of the American Academy of Religion 78: 413-48. [CrossRef]

Stark, Rodney, and Roger Finke. 2000. Acts of Faith: Explaining the Human Side of Religion. Berkeley: University of California Press.

Stepan, Alfred, and Charles Taylor, eds. 2014. Boundaries of Toleration. New York: Columbia University Press.

Stevens, Ralph. 2018. Protestant Pluralism. Suffolk: Boydell Press.

Stout, Jeffrey. 2004. Democracy and Tradition. Princeton: Princeton University Press.

Stout, Jeffrey. 2010. Blessed Are the Organized: Grassroots Democracy in America. Princeton: Princeton University Press.

Taylor, Charles. 2007. A Secular Age, 1st ed. Cambridge: The Belknap Press of Harvard University Press.

Taylor, Mark Lewis. 2011. The Theological and the Political: On the Weight of the World. Minneapolis: Fortress Press.

White, Daniel E. 1804. 'With Mrs Barbauld It Is Different': Dissenting Heritage and the Devotional Taste. In Women, Gender and Enlightenment. London: Palgrave Macmillan, pp. 474-92.

Williams, Rowan. 2015. Faith in the Public Square. London and New York: Bloomsbury Continuum. First published 2012.

Wollstonecraft, Mary. 1989. The Works of Mary Wollstonecraft. Edited by Marilyn Butler and Janet Todd. London: W. Pickering.

(C) 2019 by the author. Licensee MDPI, Basel, Switzerland. This article is an open access article distributed under the terms and conditions of the Creative Commons Attribution (CC BY) license (http://creativecommons.org/licenses/by/4.0/). 